\title{
Structural evolution of a surge-type polythermal glacier: Hessbreen, Svalbard
}

\author{
Michael J. Hambrey, ${ }^{1}$ Julian A. Dowdeswell ${ }^{2}$ \\ ${ }^{1}$ School of Biological and Earth Sciences, Liverpool John Moores University, Byrom Street, Liverpool L3 3AF, England \\ ${ }^{2}$ Centre for Glaciology, Institute of Earth Studies, The University of Wales, Aberystwyth ST23 3DB, Wales
}

\begin{abstract}
Hessbreen is a small valley glacier which last surged in 1974, and is typical of many polythermal glaciers in Svalbard. The present ice surface displays a wide range of structures that can be attributed to either quiescent-phase or surge-phase deformation. During quiescent-phase flow, primary stratification becomes slightly deformed into low-amplitude open folds, while a completely new structure, longitudinal foliation, develops in axial-planar relationship to these folds. The propagation of a surge front is associated with the formation of thrusts; however, not all of these break through to the surface. As the surge progresses, and the ice behind the surge front becomes extensional, the surface of the glacier breaks up into numerous crevasses, of which several hundred metre long transverse crevasses, convex up-glacier, are dominant. After a period of quiescence, these become degraded into crevasse traces, planar structures which are steeply dipping and have many different orientations. Overall, most ice which reaches the snout has not undergone significant cumulative strain, as indicated by the lack of deformation of both the primary structures and the later crevasse traces. The distribution of debris in Hessbreen is controlled strongly by the development of some of these structures. Angular supraglacial debris is intimately associated with stratification, while basal debris is lifted to en- and supraglacial positions in association with thrusting.
\end{abstract}

\section{INTRODUCTION}

Documenting the physical changes in a glacier during a surge is one of the most challenging tasks in glaciology. Structural investigations, however, provide a means of determining certain aspects of the bulk dynamics of surgetype glaciers for both their quiescent and active phases. The most comprehensive studies of the dynamics and structures of surge-type glaciers have been undertaken in southeastern Alaska. There, the glaciers are temperate, and have surge periodicities on the order of 10-50 years, a high rate of accumulation and a surge duration of a few to 18 months (e.g. Kamb and others, 1985; Raymond and others, 1987; Raymond and Harrison, 1988; Sharp and others, 1988).

In contrast, polythermal glaciers are prone to less frequent, slower and longer-duration surges. Examples have been described from Yukon Territory, Canada (e.g. Clarke and others, 1984; Clarke and Blake, 1991), and Svalbard (Liestøl, 1969, 1993; Dowdeswell and others, 1984, 1991; Dowdeswell, 1986; Hagen, 1987; Hagen and others, 1993). The overall structure of these glaciers, however, is relatively poorly known, although specific aspects of their structural evolution have been described, notably crevasse patterns (Hodgkins and Dowdeswell, 1994) and thrusts (Hambrey and others, 1996). This paper aims to provide an integrated analysis of all the structures displayed in a self-contained polythermal glacier of simple shape in Svalbard (Fig. 1). Structures relating to surge and quiescent phases are identified and a structural sequence defined.

\section{SURGE-TYPE GLAGIERS IN SVALBARD}

Svalbard (about $77-80^{\circ} \mathrm{N}$ ), which is $60 \%$ glacierized (Hagen and others, 1993), has a maritime Arctic climate influenced by the northern limit of the North Atlantic Drift. The climate of the western coastal areas is best represented by the permanent meteorological station at $\mathrm{Ny}-\AA$ Alesund $\left(78^{\circ} 50^{\prime} \mathrm{N}\right)$, where the mean annual temperature for the period $1971-91$ was $-6.1^{\circ} \mathrm{C}$ and precipitation $373 \mathrm{~mm}$ year $^{-1}$ (Sollid and others, 1994).

At least $35 \%$ of glaciers in Svalbard are considered to be surge type, based on detailed studies of ice surface features, such as medial moraines, on aerial photographs (Hamilton and Dowdeswell, 1996). However, at any one time, only a few of these glaciers may be surging (Dowdeswell and others, 1995). The duration of the quiescent phase in Svalbard surge-type glaciers is estimated to be of the order of 50500 years, the surge may last 3-5 years and its cessation appears to be gradual (Dowdeswell and others, 1991). There are some indications, as in the Yukon (Clarke and others, 1984), that surge-type glaciers are preferentially developed on softer sedimentary rocks as opposed to more resistant metamorphic rocks (Hamilton and Dowdeswell, 1996). Softer sedimentary rocks of Carboniferous to Palaeogene age are dominant in central Svalbard, where Hessbreen is located (Norsk Polarinstitutt, 1990).

Several glaciers in Svalbard have been investigated for their thermal characteristics. Extensive areas of temperate ice exist beneath cold surface layers in the accumulation 


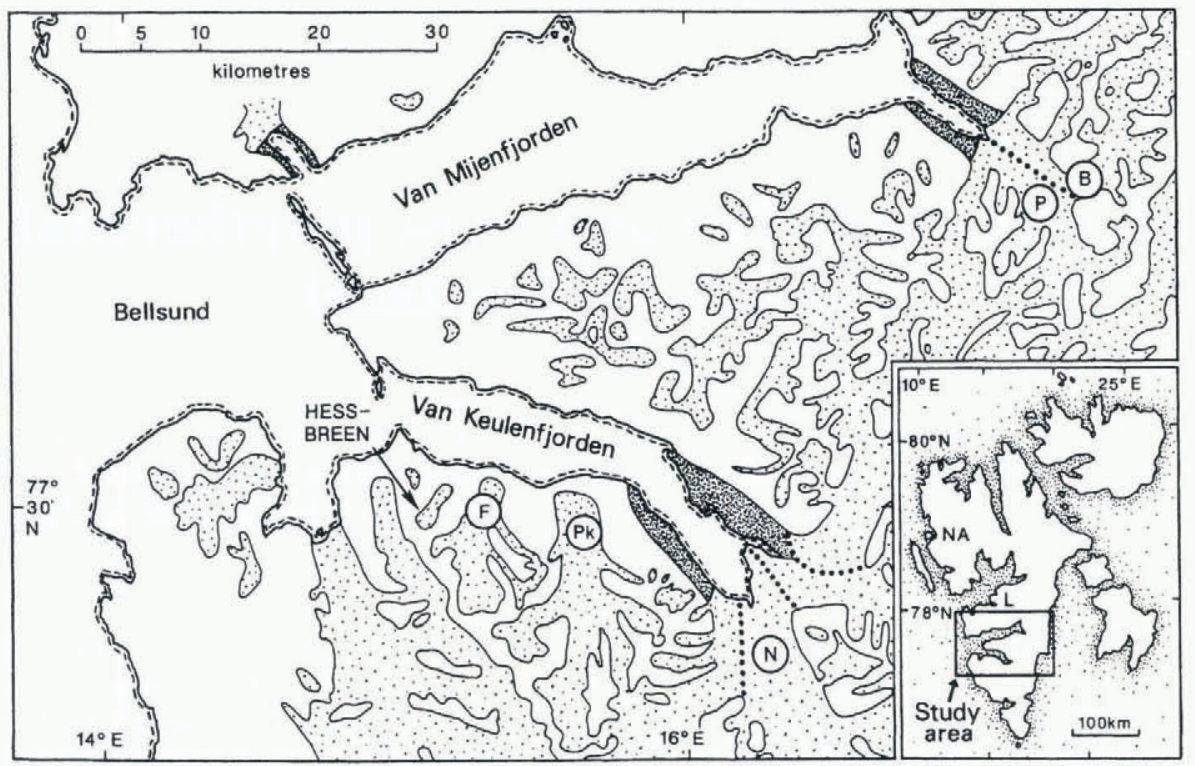

Fig. 1. Location map of Hessbreen and other glaciers in south-central Spitsbergen. F, Finsterwalderbreen; Pk, Penckbreen; $\mathcal{N}$, Nathorstbreen; P, Paulabreen; B, Bakaninbreen. Light stipple represents glacierized areas (generalised); heavy stipple represents surge-moraine systems of Paulabreen and Nathorstbreen. The coast is indicated by the solid and dashed line. The study area within Svalbard is inset ( L, Longyearbyen; $\mathcal{N} A, \mathcal{N} y$-Alesund).

area of some larger glaciers, whereas ice in at least the thinnest, terminal part of the ablation area is commonly below the pressure-melting point and frozen to the bed (Hagen and Sætrang, 1991; Ødegård and others, 1992; Etzelmüller and others, 1996). In this type of glacier, evidence from meltwater geochemistry suggests the presence of an active basal hydrological system (Wadham and others, 1996). Some smaller glaciers are, however, frozen to their beds throughout, with no apparent basal water system (Hodgkins and others, 1995).

\section{AREA OF INVESTIGATION}

Hessbreen, which last surged in 1974 (Liestøl, 1976), is one of several surge-type glaciers on the southern flank of Van Keulenfjorden (Figs 1 and 2). Hessbreen has receded only a few hundred metres from the limit of the last surge, and, as indicated by the height of the lateral moraines, subsided by only $20 \mathrm{~m}$ from its maximum ice-marginal height. It is $6 \mathrm{~km}$ long, and its $3 \mathrm{~km}$ wide accumulation basin feeds a tongue that narrows from 1.5 to $1.0 \mathrm{~km}$ in width. It is joined on its western side by ice from a small cirque, but this is almost entirely debris-covered (Fig. 2). The western flank of the glacier is precipitous, the peak of Berzeliustinden (1205 m) rising abruptly for some $900 \mathrm{~m}$ above the glacier surface. Snow-avalanche cones provide localised accumulation at 250-350 ma.s.l. The backwall is similarly steep, with ice aprons extending up to the summit ridge at $985 \mathrm{~m}$. Superimposed ice covered the ice surface above $300 \mathrm{~m}$ when investigations were undertaken (late July-early August 1995), but the equilibrium line is probably around $500 \mathrm{~m}$ from observations on neighbouring Finsterwalderbreen (Nuttall and others, 1997),

Debris on the surface of Hessbreen is limited to (i) medial moraines that emerge approximately $2 \mathrm{~km}$ from the snout; (ii) discrete rockfalls, deformed by ice flow, derived from Berzeliustinden; (iii) patches of debris, scattered apparently randomly over the glacier surface; (iv) debris derived from the bed by a variety of tectonic processes in the ice, mainly along the margins and at the snout; and (v) englacial and supraglacial channel debris at the boundaries between active and stagnant ice. Small moraine loops, typical of surge-type glaciers (e.g. Meier and Post, 1969; Clarke, 1991; Paterson, 1994), occur near the eastern margin (Fig. 2).

The margins of the glacier are defined by discrete icecored lateral moraines, separated from clean ice by an abrupt change in slope, allowing meltwater streams to become channelled along the sides. Sediment flows on the glacier-facing slopes are abundant. Within a side-valley at the eastern margin, kame terraces are present; these are probably made of glaciofluvial and glaciolacustrine sediment, formed when an ice-marginal/supraglacial lake occupied this site. Much of the sediment was deposited on dead ice, and the area shows abundant signs of collapse and glacier karst. The snout of the glacier slopes gently into a lake and onto irregular hummocky ground, beyond which

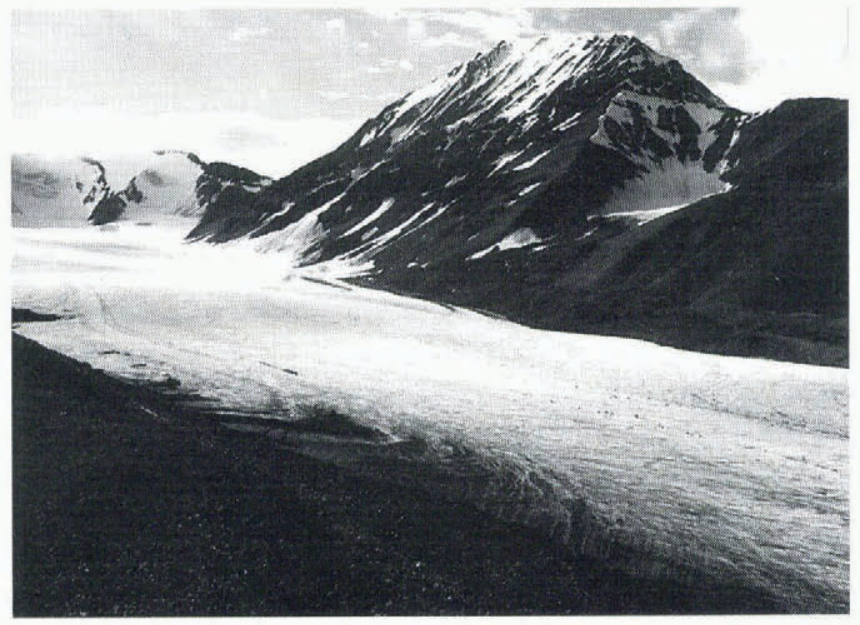

Fig. 2. Middle part of Hessbreen looking southwest towards Berzeliustinden and headwall. Note small cirque glacier upper right, rock fall and avalanche debris below the peak, looped moraines in foregound, faint longitudinal foliation to the left and various fracture systems. 
Table 1. Summary of principal structures in Hessbreen

Planar structures

$\begin{array}{ll}\mathrm{S}_{0} & \text { Stratification } \\ \mathrm{S}_{1} & \text { Early crevasse traces } \\ \mathrm{S}_{2} & \text { Foliation; foliation boudinage } \\ \mathrm{S}_{3} & \text { Thrusts } \\ \mathrm{S}_{4} & \text { Late crevasse traces }\end{array}$

Folds

$\mathrm{F}_{1} \quad$ Folds not recognisable

$\mathrm{F}_{2} \quad$ Open to tight folds mainly affecting $\mathrm{S}_{2}$

$\mathrm{F}_{3} \quad$ Recumbent folds with sheared-off lower limbs associated with thrusting

is a well-defined outer moraine that was reactivated during the 1974 surge.

From surface observations, the hydrology of the glacier appears to be simple. Supraglacial melt streams are mainly small, the largest occurring at the margins. The latter flow for several hundred metres before disappearing down moulins. The marginal melt streams emerge on either side of the glacier at the snout, the largest by far being that on the western side. In mid-August 1995, a linear zone of upwelling developed adjacent to the medial moraine but from beneath outwash material several metres beyond the apparent ice margin, indicating a link with extensive areas of debris-covered dead ice inside the moraine limit. Such a phenomenon has been observed near other ice margins in Svalbard (Hambrey, 1984).

The 1974 surge of Hessbreen was described briefly by Liestøl (1976), but there are few other data, and its earlier history is not known, although from aerial photographs there is no evidence that the glacier had surged in the pre- ceding half-century. A good illustration of the glacier in its surge state may be found on the cover of the geological map for this area (Norsk Polarinstitutt, 1990). The centre and sides of the glacier were characterised by wide, open transverse crevasses. There were two main sets of convex upglacier crevasses, each up to several hundred metres long. A longitudinal belt of short transverse crevasses occurred between the two sets of convex up-glacier crevasses, representing a zone of intense shear between the two ice-flow units. Irregularly orientated, flow-parallel linking crevasses resulted in considerable break-up of the ice surface. At the western margin, a belt of short marginal crevasses developed, representing a narrow shear zone at the margin of the fast-moving surging ice.

\section{STRUGTURAL GLAGIOLOGY}

The most detailed work on the structures of a surge-type glacier was undertaken on the temperate Variegated Glacier, Alaska, where discrimination was possible between quiescent-phase structures (mainly ductile) and surgephase structures (mainly brittle) (Lawson and others, 1994; Sharp and others, 1994). Similar relationships may be observed in the tongue of Hessbreen. Several generations of structures may be distinguished, labelled $\mathrm{S}_{0}, \mathrm{~S}_{1}, \mathrm{~S}_{2}, \mathrm{~S}_{3}$ and $\mathrm{S}_{4}$ in order of formation (Table 1 ), following normal conventions in structural geology. The principal structures visible in aerial photographs are $\mathrm{S}_{2}$ and $\mathrm{S}_{3}$ (Fig. 3).

\section{Primary structures}

The dominant primary structure is stratification $\left(\mathrm{S}_{0}\right)$ inherited from snowfalls in the accumulation area. In the tongue it forms no regular pattern, individual layers dipping gently

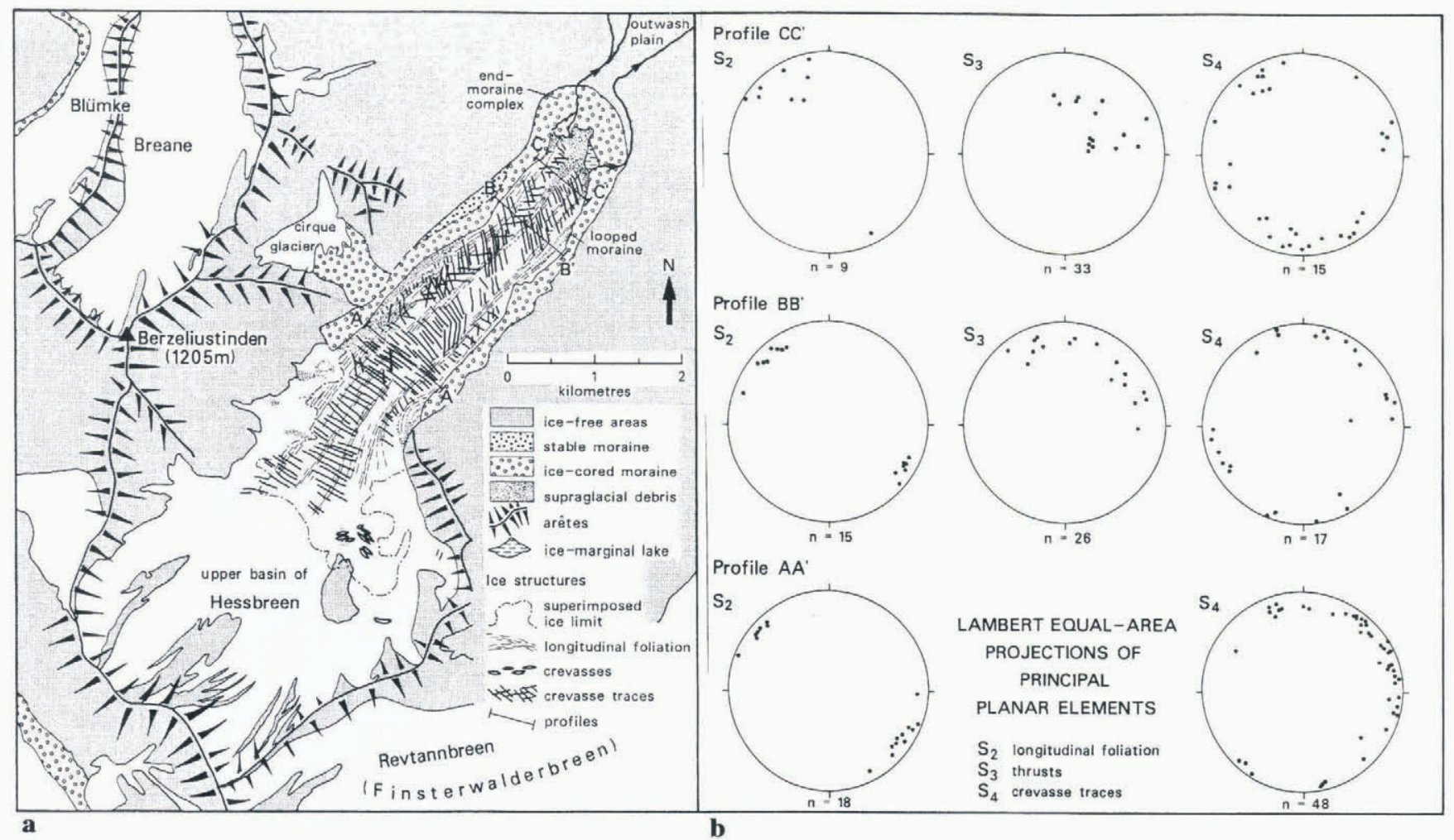

Fig. 3. Structural sketch-map of Hessbreen and surrounding geomorphology, uncorrected from 1995 aerial photograph of Norsk Polarinstitutt. Lambert equal-area lower-hemisphere projections of principal structures on the three transverse profiles marked on the map. 

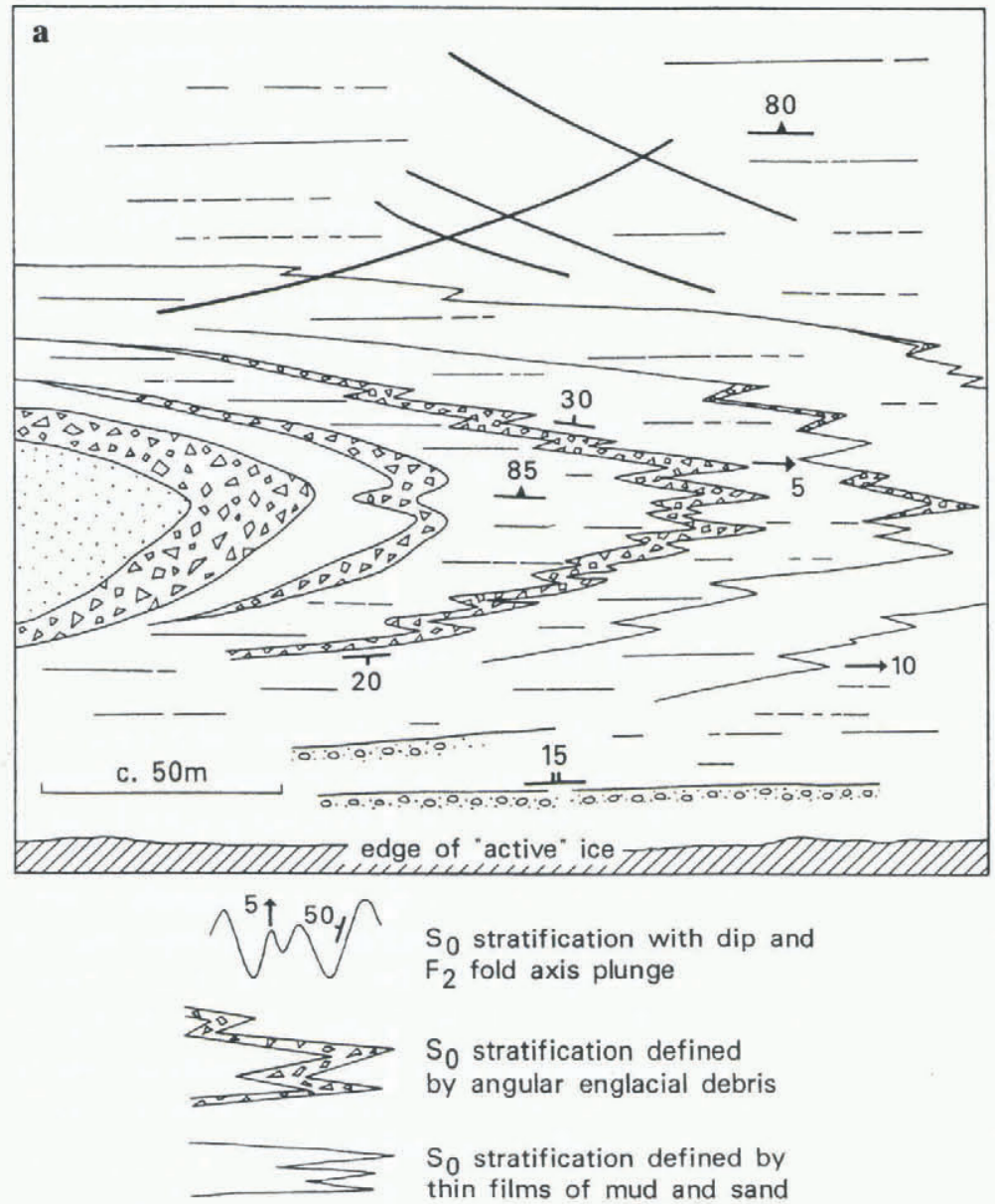

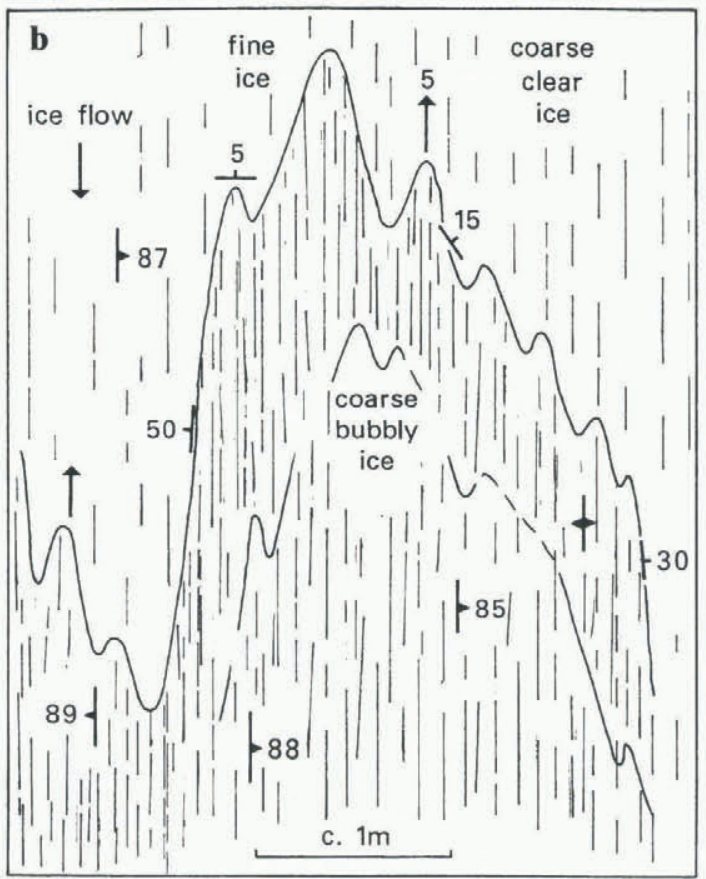

$\mathrm{S}_{2}$ longitudinal foliation with dip

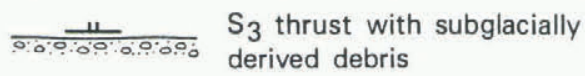

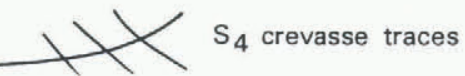

Fig. 4. Schematic plan-viewes of structural relations (a) near the eastern margin between profiles $B B^{\prime}$ and $C C^{\prime}$ (see also Fig. 2; foreground), and (b) in mid-glacier on profile $B B^{\prime}$.
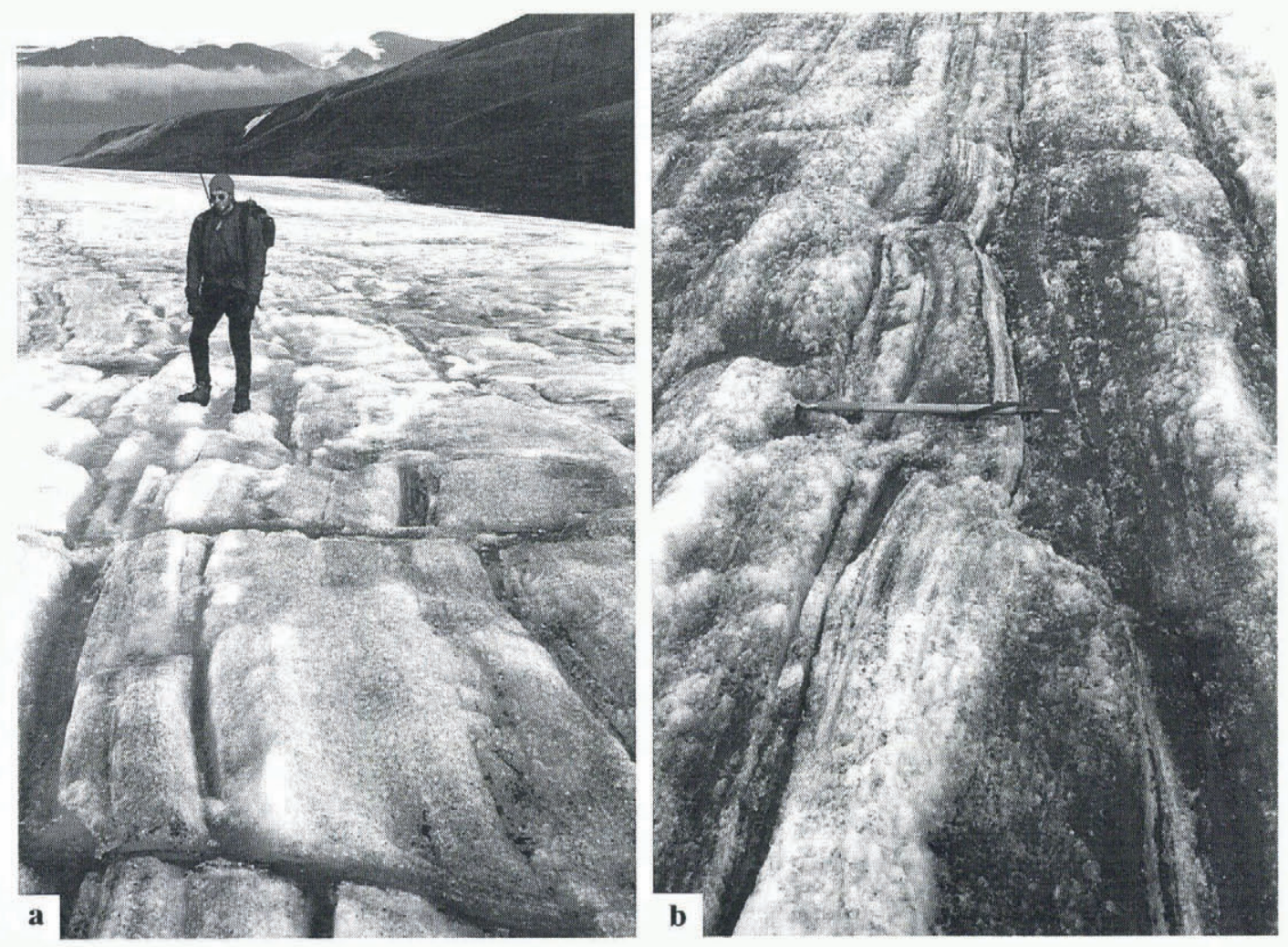

Fig. 5. Structures near eastern side of profile $A A^{\prime}$. (a) Strong longitudinal foliation $\left(S_{2}\right)$ displaced by crevasse traces $\left(S_{4}\right)$; note sinistral displacement of foliation along crevasse traces. (b) Asymmetric foliation boudinage with "necking" above and below ice axe; view down-glacier. 
in all directions. Stratification is defined by alternations of coarse bubbly ice layers up to a few decimetres thick, and thinner layers of coarse clear ice typically less than $0.1 \mathrm{~m}$ thick; the latter represent summer melt layers of saturated snow or superimposed ice. Exceptionally, coarsely crystalline clear ice (grain-size up to $0.2 \mathrm{~m}$ ) has formed out of more bubbly ice by recrystallisation. Such ice is common near the snout, but stratification is barely visible there. Individual layers may be traced in irregular fashion across the glacier surface. In some areas, stratification is picked out more clearly by layers of angular debris derived from rock falls (Fig. 4a). Although stratification is largely undeformed, reflecting passive transfer of ice through the glacier, locally it is folded, particularly in the vicinity of flow-unit boundaries.

\section{Ductile secondary structures}

The principal structure in this category is longitudinal foliation $\left(\mathrm{S}_{2}\right.$; Fig. 5a). It is not so well developed as in non-surgetype glaciers of similar geometry (e.g. Hambrey and Müller, 1978), and only in a few narrow zones, related to flow unit boundaries, does it become strong. Regardless of its strength, it maintains a steep dip, and near-uniform orientation parallel to the valley sides throughout the tongue (Fig. 3). Near the snout, foliation is weak or absent. Most foliation consists of subtle bands of coarse bubbly ice in intercalated layers. Where it becomes strong, fine-grained ice, weathering to white firn-like material, is also evident. In such areas differential weathering results in a ridged-andfurrowed surface appearance, enhanced by small streams. Near the margins of the glacier the longitudinal foliation is associated with films of debris of mud-to-pebble grade.

Foliation commonly forms an axial-planar relationship with folded stratification (Fig. $4 \mathrm{a}$ and b). In low-amplitude folds the foliation clearly bisects the stratification, and the fold axes are parallel to the foliation, and are hence designated $\mathrm{F}_{2}$. Tighter folds show $\mathrm{F}_{2}$ fold limbs approaching parallelism with $\mathrm{S}_{2}$, but the axial-planar relationship is maintained, and no transposed foliation of the type described from other glaciers (Hambrey 1977) has been observed. Furthermore, $\mathrm{S}_{2}$ must be a completely new structure, rather than be derived directly from the earlier layering (cf. Hooke and Hudleston, 1978). All folds are of the "similar" type, and the tighter ones occur where foliation is strongest.

In areas of strong foliation development, asymmetric foliation boudinage (Hambrey and Milnes, 1975) is developed locally (Fig. 5b). Overall, the foliation appears to form in a zone of transverse compression, such as where the various flow units merge before entering the confined channel. Subsequently, modification may have occurred in a rotational strain regime to generate the boudinage structure, as indicated by the asymmetry. Such structures are typical of quiescent-phase deformation (Lawson and others, 1994).

\section{Brittle structures}

Fracturing of the ice surface to depths of some tens of metres is indicated by a range of brittle structures interpreted as crevasse traces. Two main sets have been identified. The first set $\left(\mathrm{S}_{1}\right)$ is defined at the surface by occasional irregular lines extending for tens of metres across the glacier. The irregularity is due to small-scale displacements associated with shear parallel to longitudinal foliation $\left(\mathrm{S}_{2}\right)$. More dominant are straighter crevasse traces $\left(\mathrm{S}_{4}\right)$ which displace the foli- ation and so postdate it. These are steeply dipping, often extend for more than $50 \mathrm{~m}$ and are commonly, but not exclusively, orientated transverse to flow (Figs 3 and 5a). Both types of crevasse trace are marked by clearly defined layers of coarse clear ice several centimetres wide, and occasionally by zones of firn-like ice up to $1 \mathrm{~m}$ wide. Little rotation of these features is apparent down-glacier.

Fractures $\left(\mathrm{S}_{3}\right)$, interpreted as thrusts, extend from the bed, and reach the surface, mainly in the lower part of the glacier (Fig. 3; lower two profiles). Cross-sections in low ice cliffs along the eastern margin demonstrate the connection between the surface and the bed of the glacier. Indications of thrust displacement are the associated recumbent folds with sheared-off lower limbs. Also at the eastern margin, the thrusts are arrayed at an angle to the ice margin, and form curving, occasionally intersecting arcs, which extend across the glacier for several tens of metres. Near the bed they are near-horizontal; some may be observed to propagate from steps in the bed, steepening to a moderately high angle $\left(60-70^{\circ}\right)$ at the surface. However, not all thrusts reach the surface, and these may therefore be considered as "blind". At the snout, thrusts become the dominant structure and two sets are apparent, each related to a separate flow unit, divided by a medial moraine. Because originally deeper ice is exposed at the snout, the dip of the thrusts is much reduced $\left(10-30^{\circ}\right)$. Thrusts are usually made up of coarse clear ice zones a few centimetres thick, with crystals exceptionally reaching a size of $10 \mathrm{~cm}$. Debris is commonly associated with thrusts, ranging from cobble-grade material clearly derived from the basal layer (subangular to subrounded clasts, abundant mud matrix, striated and faceted clasts) to thin layers of mud. Debris rarely reaches the surface except at the margins and at the snout. Associated with some thrusts is a parallel foliation with much interstitial debris, which is indicative of strong shear adjacent to the thrust. In many non-surge-type glaciers, thrusts reactivate pre-existing planar fractures, such as healed crevasses or crevasse traces (Hambrey and Müller, 1978). However, there are no geometrical relationships visible in Hessbreen to indicate such a process, so here they are inferred to be entirely new structures.

A locally developed set of miscellaneous fractures, visible in the eastern ice cliffs at the margin and having broadly the same geometry as the thrusts, shows displacements in the opposite direction of up to $1 \mathrm{~m}$. These reverse faults are evidently rotated extensional structures, such as crevasse traces, but their relative age has not been established.

At the time of this investigation (1995), Hessbreen was well into its quiescent phase and there was a near-complete absence of crevasses or other indications of active fracturing. From this it follows that most of the brittle fractures were developed during surge-phase flow.

\section{DISGUSSION}

\section{Structural evolution}

Intersecting relationships have enabled us to determine the sequential development of structure in Hessbreen, as denoted by the designations $\mathrm{S}_{0}-\mathrm{S}_{4}$ for planar features, and their equivalents for folds. In deformed rocks, the different assignations are commonly regarded as discrete events acting over a wide area. In Hessbreen, and glaciers generally, the sequence of events applies to a small body of ice moving 
through the glacier, not the whole glacier. Thus, at any one time, late structures (e.g. fractures, $\mathrm{S}_{4}$ ) may be forming at the same time as thrusts $\left(\mathrm{S}_{3}\right)$.

Although this analysis has used the normal notations of planar structures in structural geology, the order of formation should not be considered in a truly temporal sense (Hambrey and Milnes, 1977). Rather, the progressive development of structures in terms of phases of structural development refers to the passage of a "parcel" of ice as it moves through the glacier to the snout. With this proviso, the following events, affecting the parcel of ice as it moves through the glacier system, may be identified.

\section{Quiescent phase 1}

Development of stratification $\mathrm{S}_{0}$ in the accumulation basin. Rock falls debris over the surface of the glacier and become concentrated at a particular stratum, forming marker horizons.

\section{Surge phase 1}

Fracturing of ice and crevasse development takes place, giving rise to early crevasse traces $\left(\mathrm{S}_{1}\right)$ whilst still in the upper basin.

\section{Quiescent phase 2}

Development of foliation $\left(\mathrm{S}_{2}\right)$ by lateral compression as the ice moves out of the upper basin into the confined channel. Small, centimetre-scale displacements, resulting from shear parallel to the foliation, are indicated by irregular wavy trends to the $S_{1}$ fractures, and by open, similar and isoclinal folds $\left(\mathrm{F}_{2}\right)$ in axial-planar relationship to the foliation. The foliation is well developed only near the margins and at flow-unit boundaries.

\section{Surge phase 2}

Following the initiation of a new surge in the upper basin, the surge front moves rapidly into the confined channel, subjecting the ice to strong longitudinal compression. Thrusts $\left(\mathrm{S}_{4}\right)$ develop, propagating from the bed, and lifting basal debris into an englacial position. From observations at surge-type glaciers where prominent longitudinal cliff sections are present (e.g. Bennett and others, 1996), many thrusts do not propagate to the surface and are therefore blind. They become exposed only as the ice ablates as it approaches the snout, or are visible in profile at the eastern margin. Following passage of the surge front as a kinematic wave, the ice becomes subject to extending flow and undergoes heavy crevassing. Extensional veins extend to the sides of and below open crevasses. As the crevasses ablate or close, numerous crevasse traces are left behind $\left(\mathrm{S}_{4}\right)$; they are predominantly transverse, but also have several other orientations, commonly forming intersecting sets.

\section{Comparison between surge- and non-surge-type glaciers}

From our observations at several surge- and non-surge-type glaciers in Svalbard, a number of structural differences may be identified:

(i) Surge-type glaciers in their quiescent state have a much greater density of crevasse traces, a characteristic that is linked to the all-pervasive nature of fracturing during a surge.

(ii) Surge-type glaciers have few open crevasses in their quiescent state, although this may also apply to slow- moving non-surge-type glaciers under a strongly negative mass-balance regime.

(iii) Thrusts are common in both surge- and non-surge-type polythermal glaciers in Svalbard, although for temperate glaciers thrusts are usually abundant only in surge-type glaciers (Sharp and others 1988; Lawson and others, 1994). There is some evidence to suggest (in aerial photographs) that, in the surge-type glaciers of Svalbard, thrusts may occasionally reach the surface not just near the snout but also in the higher reaches.

(iv) Longitudinal foliation tends to be better developed in non-surge-type glaciers than in surge-type glaciers of similar shape. This structure normally forms in axialplanar relationship to stratification (Fig. 4b), and in surge-type glaciers is limited to narrow zones parallel to flow, especially at the boundaries between flow units.

(v) Looped moraines are normally associated only with surge-type glaciers and are related to non-synchronous pulsatory flow in adjacent flow units. Loops investigated on Hessbreen, on the adjacent Finsterwalderbreen and on Pedersenbreen near Ny-Ålesund (Fig. 1) all represent a gently dipping folded stratum or group of strata comprising angular rock-fall debris. Longitudinal foliation $\left(\mathrm{S}_{\mathrm{l}}\right)$ forms a clear axial-planar relationship with the folded debris strata in the looped moraines (Fig. 4a).

(vi) The total amount of strain undergone by glacier ice is reflected in the strength of foliation (Hambrey and Milnes, 1977). In the case of Hessbreen and other surgetype glaciers in Svalbard, the limited development of foliation and relative lack of tight folding of stratification is indicative of low total strains. High total strains in Hessbreen are confined to the margins (and presumably the bed), and to the boundaries between flow units. In contrast, a non-surge-type glacier of similar shape may have all-pervasive foliation, indicative of high total strains throughout.

\section{GONGLUSIONS}

The structural evolution of Hessbreen resembles that of temperate Variegated Glacier, Alaska (Lawson and others, 1994), in that ductile deformation dominates the quiescent phase, and brittle fracture the surge phase. It may also be noted that the total strain undergone by the ice, as indicated by the presence of ductile structures, is much less than in non-surge-type glaciers. This confirms the widely held view that the bulk of the ice is transferred through the system by "plug flow" during a surge, and that quiescent-phase deformation, despite the length of time between surges (typically several decades or longer in Svalbard; Dowdeswell and others, 1991), is relatively limited, certainly when compared with non-surge-type glaciers.

The structural development of Hessbreen is intimately associated with debris transfer. As has been noted at Bakaninbreen (Hambrey and others, 1996) and at Kongvegen near Ny-Ålesund (Bennett and others, 1996), thrusts play a significant role in raising basal debris to an englacial position. Debris incorporation into basal crevasses, as has been described from a surge-type glacier in Iceland (Sharp, 1985), does not appear to have taken place at Hessbreen. Foliation development at the margins is also associated with 
the incorporation of basal debris, whereas supraglacial debris becomes buried and folded in combination with stratification.

\section{ACKNOWLEDGEMENTS}

This work was funded by European Union Environment Programme grant EN5V-CT93-0299. Financial support was also received from Liverpool John Moores University. For assistance with the fieldwork we thank D. Garbett and A. Bingham.

\section{REFERENCES}

Bennett, M. R., M. J. Hambrey, D. Huddart and J. F. Ghienne. 1996. The formation of a geometrical ridge network by the surge-type glacier Kongsvegen, Svalbard. 7. Quat. Sci., 11(6), 437-449.

Clarke, G. K. C. and E.W. Blake. 1991. Geometric and thermal evolution of a surge-type glacier in its quiescent state: Trapridge Glacier, Yukon Territory, Canada, 1969 89. J. Glaciol., 37(125), 158-169.

Clarke, G. K. C., S. G. Collins and D. E. Thompson. 1984. Flow, thermal structure, and subglacial conditions of a surge-type glacier. Can. 7. Earth Sci., 21 (2), 232-240.

Clarke, T. S. 1991. Glacier dynamics in the Susitna River basin, Alaska, U.S.A. 7. Glaciol., 37 (125), 97-106.

Dowdeswell, J. A. 1986. Drainage-basin characteristics of Nordaustlandet ice caps, Svalbard. 7. Glaciol., 32(110), 31-38.

Dowdeswell, J. A., D. J. Drewry, O. Liestøl and O. Orheim. 1984. Airborne radio echo sounding of sub-polar glaciers in Spitsbergen. Nor. Polarinst. Skr. 182.

Dowdeswell, J. A., G. S. Hamilton and J. O. Hagen. 1991. The duration of the active phase on surge-type glaciers: contrasts between Svalbard and other regions. 7. Glaciol., 37(127), 388-400.

Dowdeswell, J. A., R. Hodgkins, A. -M. Nuttall, J. O. Hagen and G. S. Hamilton. 1995. Mass balance change as a control on the frequency and occurrence of glacier surges in Svalbard, Norwegian High Arctic. Geophys. Res. Lett., 22 (21), 2909-2912.

Etzelmüller, B., J. O. Hagen, G. Vatne, R. S. Ødegård and J. L. Sollid. 1996. Glacial debris accumulation and sediment deformation influenced by permafrost: examples from Svalbard. Ann. Glaciol., 22, 53-62.

Hagen, J. O. 1987. Glacier surge at Usherbreen, Svalbard. Polar Res., 5(2), 239-252.

Hagen, J. O. and A. Sxtrang. 1991. Radio-echo soundings of sub-polar glaciers with low frequency radar. Polar Res., 9(1), 99-107.

Hagen, J. O., O. Liestøl, E. Roland and T. Jørgensen. 1993. Glacier atlas of Svalbard and Jan Mayen. Nor. Polarinst. Medd. 129.

Hambrey, M.J. 1977. Foliation, minor folds and strain in glacier ice. Tectonophysics, 39(1-3), 397-416.

Hambrey, M. J. 1984. Sedimentary processes and buried ice phenomena in the pro-glacial areas of Spitsbergen glaciers. f. Glaciol., 30(104), 116-119.

Hambrey, M. J. and A. G. Milnes. 1975. Boudinage in glacier ice - some examples. J. Glaciol., 14 (72), 383-393.

Hambrey, M.J. and A. G. Milnes. 1977. Structural geology of an Alpine glacier (Griesgletscher, Valais, Switzerland). Eclogae Geol. Helv., 70 (3), 667-684.
Hambrey, M.J. and F. Mülier. 1978. Structures and ice deformation in the White Glacier, Axel Heiberg Island, Northwest Territories, Canada. f. Glaciol., 20 (82), 41-66.

Hambrey, M.J., J. A. Dowdeswell, T. Murray and P. R. Porter. 1996 Thrusting and debris entrainment in a surging glacier: Bakaninbreen, Svalbard. Ann. Glaciol., 22, 241-248.

Hamilton, G. S. and J. A. Dowdeswell. 1996. Controls on glacier surging in Svalbard. 7. Glaciol., 42(140), 157-168.

Hodgkins, R. and J. A. Dowdeswell. 1994. Tectonic processes in Svalbard tide-water glacier surges: evidence from structural glaciology. $\mathcal{j}$ Glaciol., $40(136), 553-560$.

Hodgkins, R., M. Tranter and J. A. Dowdeswell. 1995. The interpretation of hydrochemical evidence for meltwater routing at a high Arctic glacier. International Association of Hydrological Sciences Publication 228 (Symposium at Boulder 1995 - Biogeochemistry of Seasonally Snow-Covered Catchments), 387-394.

Hooke, R. LeB. and P.J. Hudleston. 1978. Origin of foliation in glaciers. 7. Glaciol., 20 (83), 285-299.

Kamb, B. and 7 others. 1985. Glacier surge mechanism: 1982-1983 surge of Variegated Glacier, Alaska. Science, 227(4686), $469-479$

Lawson, W. J., M. J. Sharp and M. J. Hambrey. 1994. The structural geology of a surge-type glacier. 7. Struct. Geol., 16(10), 1447-1462

Liestøl, O. 1969. Glacier surges in west Spitsbergen. Can. J. Earth Sci., 6(4), Part 2, 895-897

Liestøl, O. 1976. Glaciological work in 1974. Nor. Polarinst. Arbok, 1974, 183194.

Liestøl, O. 1993. Glaciers of Europe - glaciers of Svalbard, Norway. U.S Geol. Surv. Prof. Pap. 1386-E, E127-E151.

Meier, M. F. and A. Post. 1969. What are glacier surges? Can. J. Earth Sci. 6(4), Part 2, 807-817.

Norsk Polarinstitutt. 1990. Van Keulenfjorden. Oslo, Norsk Polarinstitutt. (Geological Map of Svalbard Bl1G, Scale 1:100,000.)

Nuttall, A. -M., J. O. Hagen and J. A. Dowdeswell. 1997. Quiescent-phase changes in velocity and geometry of Finsterwalderbreen, a surge-type glacier in Svalbard. Ann. Glaciol., 24 (see paper in this volume).

Odegård, R. S., S. -E. Hamran, P. H. Bø, B. Etzelmüller, G. Vatne and J. L. Sollid. 1992. Thermal regime of a valley glacier, Erikbreen, northern Spitsbergen. Polar Res., 11 (2), 69-79.

Paterson, W. S. B. 1994. The physics of glaciers. Third edition. Oxford, etc., Elsevier.

Raymond, C. F. and W. D. Harrison. 1988. Evolution of Variegated Glacier, Alaska, U.S.A., prior to its surge. 7. Glaciol., 34(117), 154-169.

Raymond, C., T. Johannesson, T. Pfeffer and M. Sharp. 1987. Propagation of a glacier surge into stagnant ice. 7. Geophys. Res., 92 (B9), 9037-9049.

Sharp, M. 1985. "Crevasse-fill" ridges - a landform type characteristic of surging glaciers? Geogr. Ann., 67A (3-4), $213-220$.

Sharp, M., W. Lawson and R. S. Anderson. 1988. Tectonic processes in a surge-type glacier. 7. Struct. Geol., 10(5), 499-515.

Sharp, M., J. Jouzel, B. Hubbard and W. Lawson. 1994. The character, structure and origin of the basal ice layer of a surge-type glacier. f. Glaciol., 40 (135), 327-340

Sollid, J. L., B. Etzelmüller, G. Vatne and R. S. Odegård. 1994. Glacial dynamics, material transfer and sedimentation of Erikbreen and Hannabreen, Liefdefjorden, northern Spitsbergen. Z Geomorphol., Supplementband 97, 123-144.

Wadham, J. L., A. J. Hodson, M. Tranter and J. A. Dowdeswell. 1997. The rate of chemical weathering beneath a quiescent, surge-type, polythermal-based glacier, southern Spitsbergen, Svalbard. Ann. Glaciol., 24 (see paper in this volume). 